\title{
Comparing and deciding: a historical note on education policy
}

\author{
Justino Magalhães* \\ Instituto de Educação da Universida de Lisboa, Lisbon \{justinomagalhaes@ie.ul.pt\} \\ Received on 20 April 2013; revised on 22 April 2013; accepted on 15 May 2013; published on 15 July 2013
}

DOI: $10.7821 /$ naer.2.2.88-94

\begin{abstract}
This article provides a 'lineage' of decisions related to education policy which takes comparison as its motive, knowledge and method. A conceptual chain of world system, internationalization, convergence in education and globalization is briefly outlined. The paper examines decision-making in education policy according to agreement, mainstreaming and production criteria, taking Latin America as the linkage and the European Community as the construction. Reasoning and enlightenment are gathered in different fields of history: culture, economics, politics and education. The present paper applies a core structuring epistemology -culled from a variety of academic domains- with comparison and decision underpinning a complex rationale where time, space, materiality, knowledge, ideas, action, and evaluation all intersect.
\end{abstract}

KEYWORDS: EDUCATIONAL POLICY, HISTORY OF EDUCATION, GLOBAL EDUCATION, EDUCATIONAL ASSESSMENT, EDUCATIONAL QUALITY

\section{WORLD-SYSTEM AND UNIVERSALIZATION}

In Sofia Coppola's film Lost in translation (2003), shot in Tokyo, the protagonist is plunged in a world that is foreign to him. Urbane, cosmopolitan, ambitious, open to adventure, he is unable to communicate, interact and (re)find himself. The expression that gives the film its title refers to what, being literally translated, nonetheless remains culturally unintelligible. Separate worlds? Globalization? Let's start again by going back in time.

At the end of the 15th century, imbued with a worldview that was more imagined than described (far less experienced), combining the daring of a gunner with the self-sacrifice of a missionary the rulers of Spain and Portugal, two nobles of their age, divided the world between them, with the papal seal. It was the Treaty of Tordesilhas, signed in 1498 , to put an end to the controversy of the uncertain location of the Indies. Three centuries later, it was the Portuguese and Spanish who were still fighting in the Amazon, fitting the Tordesilhas line by force of arms and genocide to the winding course of the Rio da Prata and quarrelling over the control of Montevideo, the main port in the south Atlantic at the mouth of that river. The ocean routes recorded on transcontinental cosmographic charts made major overland trade archaic. But the imperial states failed to establish a world economy. The transatlantic economy brought about

${ }^{*}$ To whom correspondence should be addressed: Instituto de Educação da Universidade de Lisboa

Alameda da Universidade

1649-013 Lisboa

Portugal world-economies -a concept used by Wallerstein (1974) to allude to the first two centuries of the modern period. $\mathrm{He}$ afterwards applied the concept of world economic system to the contemporary period, embracing the core, semi-periphery and periphery.

History documents an early European modernity based on an expansionist market economy and on culture - the first backed up by guns and skill and the second by religion and science. The modern rationale found support in diplomatic, commercial and statistical writings and in ocean mapping, connecting the different parts of the world. The Treaty of Vienna (1815) put paid to Napoleon's imperialism; it was a diplomatic event of worldwide significance, since the intervening powers were turning their attention to colonialism and this affected their negotiating tactics.

Giving way to the romantic federalism of nationalities and breaking away from the Ancien Régime, world fairs made their appearance from the mid-nineteenth century: the Great Exhibition in London (1851), Paris (1855), London (1862), Paris (1867), Vienna (1873); in between there were national exhibitions. These events embodied and gave meaning to scientific and technical progress. The term 'universal' combined the geography and the theme. Focused on innovation and progress these fairs were a blend of economics, culture, technique and modelling. They led to the harmonization of weights, measures and standards. One such standard was the decimal system. At the same time as spreading inventions, patents, technical applications, local produce/products strategically collected by national representatives, there were innovative scientific conferences.

With the goals of competition and innovation, the bookkeeping of those exhibitions/fairs adopted statistics as their tool for accounting and analysis, scale arrangement, standard and mode of presentation in catalogues and tables of the data from various countries relating to different goods. These exhibitions stimulated advertising, trade and the registration of inventions and patents. In fact, they aimed to circulate knowledge and harmonize ways of life and standards of development as Silveira (1874), a Portuguese manufacturer and Portugal's representative at the Vienna Exhibition had clearly expressed:

The World Fairs have made a powerful contribution to levelling industrial knowledge throughout Europe's centres; scientific, technological, special publications, the ease and openness of relations, allow us to say that, apart from rare exceptions, there are no secrets in industry today (p. 107)

As the population grew and the industrial revolution progressed in the $19^{\text {th }}$ century, Europe was the centre of a worldeconomy. 


\section{INTERNATIONALIZATION AND FEDERALISM}

Rivalries, fuelled by the Scramble for Africa and, from the 1890 s, by the confrontation between the warring blocs that erupted into the First World War, brought the meanings of world and worlds up to date. The 1914-18 War brought different worlds into opposition and, at the end, Europe had secured its empires and was still the centre of the World: "Paris, Londres, Genève sont les capitales politiques, économiques, intellectuelles du monde" (Rémond, 1989, p. 61). Russia and the United States opted for isolation. Committed to the socialist revolution, the Russian authorities prioritized the consolidation of the regime and the economic and social reforms that would ensure progress and development. Meanwhile, the United States (the "New World") made firm progress to hegemony.

The 1920 s was a decade of accelerated rivalry. The industrialization and gaining of different markets made the years 1925-29 a period of unprecedented prosperity. When the bubble burst in 1929 internationalization meant that the malaise spread swiftly to Europe and dependent economies. Unemployment was massive throughout the industrialized world. The lack of confidence in the economy and protection against the import of industrialized goods paved the way for political intervention. The freedom struggles and nationalist reconstructions had been on a journey of freedom and democracy since the early 19th century, inspired by European ideals.

Since the 1970s, development, perceived as economic growth, scientific and technical advances and better living conditions, became the key to international relations. Ranking countries by their standard of living made it possible to accentuate the contrasts, but it also fostered the diversity of relations. The developed countries were also the wealthiest and the term 'Third World' became popularly associated with South America, Asia and Africa. International trade as the driving force of economic expansion served to emphasize the interdependence of economies, definitively breaking with the nation-state framework.

The ideals set out in the Universal Declaration of the Rights of Man and the Citizen, which underpinned the 1789 Revolution, the Liberal Revolutions and modern democracies, along with the United Nations Charter and the Declaration of the Rights of the Child, gave meaning to modernization and the globalization of the ideals of freedom, justice, equality - of humanism and development, in fact - nurtured in the Europe of the Enlightenment, and tested and implemented in the $19^{\text {th }}$ and $20^{\text {th }}$ centuries. At the root of the modernizing, democratic, Enlightenment project is education, where the school was the medium and globalization was the evolutionary direction. Cyclically, these ideals have been calibrated and strengthened; cyclically, Europe is at the centre of the modelling.

\section{THE SCHOOL INSTITUTION AND GLOBALIZATION}

In the meantime, globalization had made its way. In this pedagogical-historical process the school institution was duly structured and legitimized by a political function of citizenship, urbanism and humanism. The institutionalization of the school provided the foundation, method and universality to written culture; it gradually came to express educated profiles; it legitimized school education as a sociability, access and participation; it made it possible for the school project and culture to be a condition and realization of societism and humanism. Over this lengthy period, school education was configured in a hierarchy of educated profiles: elementary, supplementary, developed/specialized, higher.

The history of schooling as an institutional component of globalization was made up of pedagogical-historical complexes of nationalities and transversality, evolutionary on the internal and internationalization level. The following chronology can be outlined: statalization, nationalization, governmentation, regimentation, universalization, diversification. In terms of Portugal, but extending - albeit with variations - to western education systems, this series of historical cycles is documented as follows. The absolute state established a proto-school system; liberalism instituted, nationalized and formalized a school culture; governmentation paved the way for an organic hierarchization and bureaucracy, which was carried out by regimentation.

The state element in public education and teaching was enshrined by the education policies of the Enlightenment, by the reforms implemented in the framework of the French Revolution (1789), and by Napoleonic imperialism. These policies built up the school as the main medium of public education, under the sovereignty of the state. The instability and intense ideology and partisanship of the liberal revolutionary period led to national education policies. The liberal reforms and romantic movement of reconstitution of nationalities saw the structuring of the primers (cartilhas maternais) and school grammar books, in the vernacular, designed to promote literacy and standardize the language. The governance of education policy and the school complex was strengthened from the third quarter of the nineteenth century with the establishment of regulations, bodies and central and local systems. This governmentation was achieved in a systemic, integrated, legislative framework, in a vertical organic system, in standardized bookkeeping.

The school element became a regular subject of World Fairs through statistical and organic bookkeeping - bureaucracy that was common to the many school contexts of the West. This organic, standardized bookkeeping was largely due to inspection systems analogous from country to country. School materials, forms, maps, classifying lists, prints, charts, calculation tables, laboratory materials were also shared, either because they were produced in the same production and distribution centres or because they were replicated by national education systems, once agreement was apparent.

The process of socio-cultural regeneration, pedagogical standardization and organic/administrative functionality paved the way for regimentation. The republican direction of education was a symbiosis between a political regime and school duty, as the Jules Ferry reforms showed in France and acceptances such as 'republican school' in Portugal. Regimentation also served socialist regimes. Reacting to 'magistro-centrism' and regimentation, the 'new school', while tolerating distinct educational setups, converged on 'pedocentrism' and the separation between matters of state and schooling. The New School Movement benefited from the new scientific framework of the social and human sciences, particularly sociology and psychology, and from the spread of ideas and scientific and educational experiments from one side of the Atlantic to the other.

Combining worldview and science, the New School Movement made it possible not only to transform society, via the school, but to (re)create humanity, too. Giving way to scientific pedagogy the school institutions became key to 
development, progress, and ideation. Nevertheless, a rapprochement between schooling and the political regime occurred in the context of the implementation of the republican and socialist regimes and the First World War. The school as representative of the nationalist cause was taken as a medium and factor in training and mobilizing people for progress and the achievement of political ideals. The regimentation of the school institution was accomplished by totalitarian regimes and dictatorships in the first half of the $20^{\text {th }}$ century. The symbiosis between school pragmatics and society was strong and in the 1920 s and 1930s an idiosyncrasy was noticed between regime ideology and school duty. In Portugal this symbiosis was emphasized with the Estado Novo (New State) and expressed in the Escola Portuguesa (Portuguese School) concept.

By the mid $20^{\text {th }}$ century the education systems had generalized the school subsystem. The comprehensive school, provided for under the Education Act (implemented in England from 1944) and the Henri Wallon reform (passed in France in 1945), became the school of the masses. With the easing of international tension after the Second World War, and prompted by the OECD and UNESCO, schooling has become steadily globalized on the basis of the Western model. Decolonization and democratization, linked to standardizing forums, such as the IMF and international conventions, ensured the universalization of education. More recently, this globalization has established regulatory tools such as PISA.

Finally, we can mention the historical cycle of diversification of which May 1968 was the first sign. Successive multiculturalisms and different pedagogies (such as the institution, community and subjects) and, more recently, multilingualism, were signs of school openness. Related to universalization, the first major crises of the school model emerged. On the one hand, the school institution had become allembracing on the vertical plane, absorbing all human ages from childhood to old age; on the other hand, with schooling accomplished (gradually translated into basic education) and extended to secondary education through the school subsystem in the $1980 \mathrm{~s}$, it became apparent that the school culture could not be kept uniform. School lost its status and authority as an institution. Paradoxically, the school subsystem had to open up to new pedagogical and didactic views and to new audiences, but it was growing increasingly weak as a standard and institution. Diversification is the term that makes it possible to point to a school reality that is ever more multicultural and, by the same token, to initiate the neo-institutional perspective in comparative studies as has been enshrined by the Comparative Studies Group from Stanford (USA).

\section{INTERNATIONAL CONVERGENCE AND SCHOOL DIVERSITY}

Internationalization movements have been breaching the nationstate boundaries since the end of the nineteenth century. The geo-economic empires were dismantled by the First World War and after the Second World War the nation-states lost sovereignty to international confederations. Industrialization and the market economy rendered frontiers obsolete and forced the agreement and implementation of confederal and world regulatory mechanisms. In the period between the two World Wars, Europe continued to dispute the parallel between the Old and New Worlds, but the hegemony of the United States (in science, art and technology) kept on growing. Having overcome the tribulations of the first phase of its existence, the League of
Nations was reborn after the Second World War, but based in the United States.

Decolonization caused the Third World to emerge, comprising the African and Asian countries that had gained independence. In the 1980s, when some of those countries had already benefited from faster development and others were steeped in poverty, the term 'Fourth World' gained popularity. Meanwhile, globalization became established in the popularization and expansion of the school model. Reconfigured in terms of the dialectic between 'magistro-centrism' and 'new-schoolism', the school ensured written acculturation to enable citizenship and humanization to join forces in the service of the nation-states. As an institution, the school ensured standardization, equality and internationalization. In the post-war period, the forums for the internationalization and integrated development of humanity (embracing economic, cultural and political development), notably the OECD and UNESCO, assigned a new priority to the school, universalizing, at the internal level, and globalizing, at international level. The world-system, inspired by European ethnocentrism, was based on the school model.

Under the influence of UNESCO and in the wake of educational and instructional integration in the $1960 \mathrm{~s}$, the systemic view was applied to pedagogy and education policies. The extension of the school model to literacy, adult education, lifelong training and higher education gave the school system a vertical direction and speeded up closure. School pedagogy was applied to new audiences and new challenges (vocational and specialized training). In the ensuing decades the school population grew exponentially. In developing countries this growth is seen particularly in basic education and subsequently in secondary and tertiary education. Since the 1990s globalization has also been associated with the new means of access to information provided by new information and communication technologies. However, the spread of these technologies in the formal education system has been slow and uneven.

Schooling has continued to grow in the developing continents and countries. Between 1999 and 2009 the percentage of children worldwide that reached their final year of primary education rose from $81 \%$ to $88 \%$. The world school system has grown in recent decades, especially in developing countries. Attendance and success figures have improved. Education for all was proclaimed in the Jomtiem Declaration - World Declaration on Education for All: Framework for Action to Meet Basic Learning Needs (March 1990). The same principle was taken up in the Salamanca Statement: on Principles, Policy and Practice in Special Need Education (June 1994) Globalization and multiculturalism compelled the opening of curricula to new topics and ethno-cultures, usually at the expense of classicism and formalism. The harder and more abstract subjects were being measured by practical and utilitarian course units. Teaching pedagogies gave way. The impact on learning and implementing performance evaluation systems aimed at achieving precise goals for school universalization. Centres of excellence have become established in the area. Thus in Finland, quality has been the watchword for compulsory education since the 1990s - Quality Assurance and Evaluation (QAE). In the first decade of the new millennium quality has become the watchword of compulsory education throughout Europe (Eurydice, 2004). 


\section{MEASURING, COMPARING, AGREEING}

In 1817 Esquisse et vues préliminaires d'un ouvrage sur l'Education Comparée, by Marc-Antoine Jullien was published in Paris. This writer, after arguing for the importance of education to "provide every person with a deep sense and practical understanding of what they should know, want and do in their sphere of activity" (Jullien, 1998, p. 20), presents a plan to understand education in the 22 cantons of Switzerland, in some parts of Germany and Italy. Subsequently, the investigation should be extended to all the states of Europe. Aware that the various governments had had the Pestalozzi and Fellenberg institutes observed, he was convinced that "the universal tendency for the same goal, the regeneration and improvement of public education (...) were a sure indication of a need shared by all governments and all people" (p. 21).

The plan that Jullien de Paris proposed for finding out how the educational reality compared in different countries consisted of 6 series of questions: a) primary and common education; b) secondary and classical education; c) higher and scientific education; d) normal education; e) education for women; f) education and its relationship with legislation and social institutions. The application of the comparative method to education issues included a previously organized survey or resulted in intellectual operations of assembling and arranging in series. According to the Dictionnaire Buisson, in the preparation of the Vienna World Exhibition of 1873 the Austro-Hungarian government sent a survey out to the governments of the various countries to obtain comparative information. The bookkeeping reflected the uniformity of the items. The accounting element forced the spread of statistics, leading the reports to become increasingly summarized.

To compare is to approximate reality and science, and it is to guide observation to understand, appraise, explain and decide. Comparing fulfils functions of attraction and spirit. Assembling, arranging in series, comparing are three scientific and cognitive activities that commanded an initial historical cycle of rationality and political decision, particularly in the field of educational innovation. Thus, the basis of the New School Movement is underpinned by judicious observation, comparison, agreement, and systematization. It was implemented by the Bureau International des Écoles Nouvelles, established in 1899 and organized in 1912. In addition to cooperation, this body coordinated comparison and made possible the system that configured and agreed 'l'idéal de l'École nouvelle' (Vasconcelos, 2000, p. 3).

Written in the form of a programme, the book by Adolphe Ferrière, Transformemos a Escola, contains the main steps of comparison as a rationale for decision. It starts with a metaphorical chaos, presents a scientific base and a conceptualization for change, proceeds to a comparative survey, agrees and applies. Finally, it proposes an overhaul of the Swiss education system whereby the guiding principles of the New School would be fulfilled. The Portuguese parliament also discussed a programme for creating New Schools. Encyclopaedic in nature, the Dictionnaire Buisson retrieved and applied the various scientific views (pedagogical, organizational, curricular, statistical) operating in the knowledge of each country.

The comparison lacks an observation, representation, bookkeeping, collation, systematization plan. Lucien Febvre acknowledged comparative studies in history. In 1928, Marc Bloch developed a comparative history of European societies which involved a comparison of contiguity and proximity between societies, linking comparison and transnationalism (cf. Bloch, 1998, p. 74). The application of the comparative method to economic history enabled the systematization of the model of basic goods and was able to explain the sequence of developmental cycles of different countries geared up for exports. Returning to the field of education, the standardization of written culture and pedagogical transversalities challenge the comparative-historical views in which historicism is combined with theorization, modelling, problem-solving and critical perspective. Neo-institutional perspectives figure in this complex.

\section{UNDER THE SIGN OF DIVERSITY - COMPARING, TRANSVERSALIZING, CONNECTING}

Even in a relatively short time civilizations start to use the same techniques as their lifestyles are drawn closer together; indeed, as Braudel (1978) concluded, "es el plural el que predomina en la mentalidad de un hombre del siglo XX" (p. 15). Fernand Braudel linked the comparatist and systemic perspectives. Comparison in education was often confined to the quantitative dimension, simplifying data and streamlining analysis. UNESCO has published education facts and figures since the mid-20th century. From the 1980s these statistics began to include differentiating aspects whose factoriality aimed at improving the understanding and explanation of different situations, so that intervention could take place in a logical rationale and qualified context. The association between situation data and action indicators was boosted in the 1990s when the UNESCO reports started being published jointly with those of the IMF. The application of comparison in the social sciences and education was the topic of the international seminar "Los usos de la comparación en ciencias sociales y en educación" (CIDE, Madrid, 7-10 February 1989). The main purpose of this seminar, whose papers were published in a special issue of the Revista de Educación, was to "dar a conocer [in Spain] así como en los países de habla española (...) nuevas orientaciones y nuevos desarrollos de la comparación en las ciências sociales y en la educación" (Pereyra, 1990, p. 17).

In an account of comparative education, António Nóvoa (1998) revisits the contribution of Marc-Antoine Jullien de Paris and systematizes the evolution of this academic domain,

(...) autour de quatre aspects essentiels, qui fournissent une espèce de grille de lecture aux efforts déployés par les différentes générations de comparatistes en vue de la consolidation de leur champ de recherche et d'action: l'idéologie du progrès, un concept de science, l'idée d'État-nation et la définition d'une méthode comparative. (Nóvoa, 1998).

Returning to these aspects to warn against simplification, Nóvoa developed a reasoning of metascience that linked a process of scientificity to each of those elements to achieve a comparison structure (cf. Nóvoa, 1998, pp. 65-68).

Regardless of multiple aspects, the comparative rationality depends on the epistemic perspective. Nevertheless, neoinstitutionalise studies have shown that global influences act on the mechanisms and the measures of access and performance, on curricular harmonization and on the structures of organization and decision. And even though, as John Meyer (2000) recognizes, the standard mechanisms may not act uniformly in 
all nations, as happens "to other sectors of global society (...), there actually is a global education system" (p. 20). But the overall school culture must continue to eliminate national and ethnocentric realities, it must involve "the construction of a 'new world"” (p. 30).

Internationalization has been handled in a twofold sense, since it combines mapping nation-states or regions with transversality. One of the ways that emphasizes the combination of otherness and innovation lies in the concept of externalization (cf. Schriewer, 2000). A comparative study of modernization processes in the USSR, China and Spain in the period from the early 1920 s to the mid-1990s was conducted by Schriewer and Martinez, members of the Humboldt University's Comparative Centre (Berlin). It found that internationalization occurred essentially through outsourcing and that there is a certain disparity between the apparent Westernization in economic and institutional terms and the persistence of cultural patterns, i.e. between power and meaning (Schriewer \& Martinez, 2004, p. 51).

Mediation has various modes of action and different profiles that include visitors and experts in national territories (passeurs, brokers), along with monitors, inspectors, and appraisers. In a collection of several case studies of globalization and internationalization, the editor, Steiner-Khamsi used the binomial "borrowing and lending" (Steiner-Khamsi, 2004). "Educational borrowing" is thus another way of saying globalization, of acknowledging the timeliness of its implications and creating a meaning to understand it. As Popkewitz (2004) warns in the preface to the same book, "If globalization is not a new historical phenomenon, the question is how to account for the present" (p. VIII).

The circulation of ideas, models and forms of government is changing. As mentioned, the convergence of school education occurs under the sign of diversification. The world school involves and challenges different pedagogies and policies despite the convergence of results and modelling of measures. At a meeting organized by the Revue International d'Éducation, on the topic "Un seul monde, une seule école?", several participants glossed the international convergence / national divergence binomial. Bernard Charlot revisited that binomial and continued with the terms globalization, internationalization (Charlot, 2009, pp. 129-137). Indeed, there is a certain paradox between the ideal school policies and the different realities in which they are implemented.

In South America the development programmes launched since the 1970s wrought major changes in the urban world and migration to cities. Associated with industrialization and inclusion policies, such programmes have generated a pancontinental awareness (Ossenbach \& Del Pozo, 2011, p. 589). Colonial and post-colonial history reveals a transversality that has been studied based on the circulation of models and cultural hybridism, which makes Latin America exceptional. Increasingly used in a number of sciences, the notion 'trans' was used by Tyrrell in "transnational history" (Ossenbach \& Del Pozo, 2011, p. 281). The perspective of transnational history is appropriate for Latin America in the post-colonial period as it embraces the notions of transfer and circulation of models and ideas. Its use was the subject of a theme issue of Paedagogica Historica (cf. Ossenbach \& Del Pozo, 2011). I myself attempted a transversal history, applying the notion of pedagogicalhistorical complexes transversalities /nationalities to the schooling of western society (cf. Magalhães, 2010, pp. 503-543).

\section{INVENTIVE REASONING IN BUILDING THE EUROPEAN EDUCATION AREA}

The creation of the European Community (particularly the construction of the European education area) has been one of the most complex projects, worked on by researchers, decision makers, actors and inspectors. António Nóvoa analysed a series of national journals (one from each country) and international journals published in Europe in the period leading up to the Maastricht Treaty (1986-1993). He concluded that "une analyse plus fine nous conduit à mieux cerner ce décalage, tout en montrant que le 'discours européen' est porté par un nombre relativement réduit d'auteurs que, dans plusieurs cas, ont déployé une activité comme 'experts' de l'Union Européenne" (Nóvoa, 1998, p. 116).

The multifactorial process of building the European education area and its configuration, in addition to variables, has been characterized by several rationales. Agreement and standardization are merely the most obvious fields. The generalization of the concept of Europeanization since the 1990s has been relating less to a semantics of transfer that served for globalization and more for a semiotics of fabricating, with new forms of governance and economic and cultural cooperation appearing on the horizon. In this respect it has been being overcome by Europeanization, of which one of the main fields is the European education area, lending continuity to 'collaboration entre les états nationaux, d'orientations au niveau de l'Union Européenne, de corporations, d'entreprises et de mouvements sociaux, de liaisons réelles et virtuelles, d'identités et de citoyennetés' (Lawn \& Nóvoa, 2005, p. 10). The shaping of a European education area stems from the Treaty of Lisbon (2000) and challenges the democratic deepening and reinvention of identities, rules of citizenship and dialogue. Europe reinventing, Europe "fabricating" is more than the Europe of states and nations: "parler d'espace européen ce n'est pas parler des limites des États de l'Union Européenne" (Coulby, 2005, p. 51).

Among the investments of the new Europe the Bologna Convention (1999) stands out. It created the European Higher Education Area, with the chief tools being the ECTS credit system ECVET, and the Europass. One application of the Europass is in the realm of modern languages. Although the Bologna Convention is concerned with policy, administration and bureaucracy, it is, above all, educational - it is pedagogy (Magalhães, 2011). For information on the implementation, diversity and results of this Convention, see the summary by Kelm (2012). Despite the convergence of school education around standards of quality and development in Europe, there are still disparities between countries and regions. Establishing education priorities is not resolved with statistics, even if it is statistics that demonstrate the disparities. UNESCO statistics have been giving way to diversity and multifactoriality since the 1980s. The focus on quality and development, marked by specific indicators of ranking, benchmarking and good practice (enshrined in Eurydice, Eurostat, OECD reports), involves and offers decision-making related to education priorities. This is borne out by a project such as "Pour une Comparaison des Politiques d'Éducation prioritaire en Europe" (cf. Demeuse, Frandji, Greger, \& Rochex, 2008), looking at compulsory schooling and preschool education in eight countries (England, Belgium, France, Greece, Portugal, the Czech Republic, Romania, Sweden). The study shows that, while the 2005 report highlights the key competences, these systems have a variation of $4.9 \%$ to $48.2 \%$ in the rates of 17 -year-olds who had not 
earned any higher secondary education qualification (Frandji, 2008, p. 11).

Education policies are subject to assessment, and this domain involves a great deal of effort at the conceptual, methodical and instrumental levels. Evaluation studies show that a relative disenchantment with "government by numbers" is associated with recognition of the contrast between "le modèle idéal des politiques scolaires dont la régulation et la transparence seraient assures", through combinations of goals and indicators of regular operation, as well as "la réalité concrète des usages contextualisés de l'évaluation qui en changent nettement le visage et révèlent des situations outres" (Felouzis \& Hanhart, 2011 , p. 30). The role of experts in national areas (passeurs and brokers) and the regulatory role of States are still crucial. Centralized regulation and standardization derived from the use of language and ICTs have not neutralized the role of comparison and good practice. Public policies are the subject of knowledge and the construction of reality, since "they are conceived as an enterprise that involves the "construction of reality' i.e. they are not intended to solve problems that are beyond them, but are in themselves processes that construct 'structures intelligibility'; 'worldviews', 'belief systems', 'representation', etc.” (Barroso \& Afonso, 2011, p. 12). One area in which European education policies have recognized that the claims of principle (EU2003) have not wholly matched practice relates to the sluggish pace with which ICTs have been deployed in the formal school system (cf. Wortian et al., 2013).

The fabrication of Europe is a field in which this entire complexity is thrown together, especially the combination of knowledge, decision, evaluation. Two major European forums of knowledge and evaluation within the European Community are the EERA, founded in 1994, and SICI, whose origin dates back to 1985. From when they were established and until now, according to Lawn (2013) these forums have

\section{(...) come to grips with a post-comparative European educational space. They had to find new ways of understanding the present of its partners end the rapidly changing visible and opaque policies of the policy space it inhabited and had to act within. They had a very short time to negotiate the cultural diversity of their members, while managing the rapid funding, policy and organizational features of the Educational or Learning Spaces emerging within the EU (p. 33).}

Comparison as critical knowledge opens into the postcomparative. Transversalization stresses diversity and forces connection, whether by implementing common goals and standards of regulation or by the interaction of different scientific and technical communities. Europe has a common history composed of singularities and transversalities, ethnocultures, forms of government, aesthetic sensitivities but the European Community is a construction of another world. It is as a construction that interaction acquires meaning and substance. It is being driven by progress. The European Community is a real and profound challenge that projects and congregates humanity; it is meta-history. The configuration of the European Community implies demos, sustained by scientific and technical knowledge in new forms of sociability and culture, in ethical designs. It is hoped that humanity and the humanitarian may be fully achieved within it. It is a material challenge of knowledge, ideation, connection, decision, evaluation and this critical reasoning is responsible for the lucidity to invent the path, respecting a multifaceted mapping of sensitivities, cultures and temporalities.

It is, at the end of the day, inventing-fabricating, with imagination, intelligence and tenacity, another world, where noone gets lost, takes other paths or lowers their sights by sparing effort or through lack of vision.

\section{REFERENCES}

Barroso, J. \& Afonso, N. (2011). Políticas educativas. Mobilização de conhecimento e modos de regulação autonomia e gestão escolar. Educação sexual e meio escolar. Avaliação externa das escolas. Vila Nova de Gaia: Fundação Manuel Leão.

Bloch, M. (1998). História e historiadores. Lisboa: Teorema.

Braudel, F. (1978). Las civilizaciones actuales. Estudo de historia económica y social ( $6^{\mathrm{a}}$ ed.). Madrid: Editorial Tecnos.

Charlot, B. (2009). Convergence internationale et diversification interne des modèles scolaires; Revue Internationale d'Éducation, 52(Décembre), 129-137. doi: 10.4000/ries.785

Coulby, D. (2005). L'éducation et l'espace européen de flux. In M. Lawn \& A. Nóvoa (Coord.). L'Europe reinventee. Regards critiques sur l'espace européen de l'éducation (pp. 51-67). Paris: L'Harmmattan.

Demeuse, M., Frandji, D., Greger, D., \& Rochex, J. Y. (Dir). (2008). Les politiques d'éducation prioritaire en Europe. Conceptions, mises en cuvre, debats. Paris: Institut National de Recherche Pédagogique.

Eurydice/ Directorate-General for Education and Culture (2004). Evaluation of Schools providing Compulsory Education in Europe. Brussels: European Commission/ European Unit.

Felouzis, G. \& Hanhart, S. (2011). Politiques éducatives et évaluation. Nouvelles tendances, nouveaux acteurs. In G. Felouzis \& S. Hanhart (Éds). Gouverner l'éducation par les nombres? Usages, débats et controverses (pp. 7-33). Bruxelles: Groupe De Boeck.

Ferriére, A. Transformemos a escola. Apêlo aos pais e às autoridades. Paris: Livraria Francesa e Estrangeira Truchy-Leroy.

Frandji, D. (2008). Introduction Générale: Pour une comparaison des politiques d'éducation prioritaire en Europe. In M. Demeuse, D. Frandji, D. Greger, \& J. Y. Rochex (Dir.). Les politiques d'éducation prioritaire en Europe. Conceptions, mises en æuvre, debats (pp. 934). Paris: Institut National de Recherche Pédagogique.

Jullien de Paris, M. A. (1998). Esboço de uma obra sobre a Pedagogia Comparada [Prefácio de Joaquim Ferreira Gomes] ( $2^{\mathrm{a}}$ ed.). Lisboa: Instituto de Inovação Educacional.

Kelm, B. M. (2012). Editorial. European Journal of Education. Research, development and policy: the Bologna process revisited, 47(3), 343-347.

Lawn, M. (2013). The understories of european education: the contemporary life of experts and professionals. Sisiphus, Journal of Education, I, 19-35.

Lawn, M. \& Nóvoa, A. (Coord.) (2005). L'Europe réinventée. Regards critiques sur l'espace européen de l'éducation. Paris: L'Harmmattan.

Magalhães, J. (2010). Da cadeira ao banco. Escola e modernização (séculos XVIII-XX). Lisboa: Educa.

Magalhães, J. (2011). A Convenção de Bolonha e a Reforma Universitária. In J. C. Souza Araújo (Org.). A universidade Iluminista (1929-2009) (Volume II: De Alfred Whitehead a Bologna, pp. 251263). Brasília: Editora Liber Livro.

Meyer, J. W. (2000). Globalização e currículo: Problemas para a teoria em Sociologia da Educação. In António Nóvoa \& Jürgen Schriewer (eds.). A Difusão Mundial da Escola. Alunos - Professores, Currículo-Pedagogia (pp. 15-32). Lisboa: Educa.

Nóvoa, A. (1998). Histoire \& comparaison (Essais sur l'Education). Lisboa: Educa.

Ossenbach, G. \& Del Pozo, M. M. (2011). Postcolonial models, cultural transfers and transnational perspectives in Latin America: A reserarch agenda. Paedagogica Historica, 47(5), 579-600. doi: 10.1080/00309230.2011.606787

Pereyra, M. A. (1990). Introducción. Revista de Educación $\left(N^{o}\right.$ Extraordinario, 1989). Los usos de la comparación en Ciencias Sociales y en Educación, 15-22.

Popkewitz, T. (2004). Foreword. In G. Steiner-Khamsi (Ed.). The global politics of educational borrowing and lending (pp. VII-XI). New York and London: Teachers College, Columbia University.

Rémond, R. (1989). Introduction à l'Histoire de notre temps. 3. Le XXe siècle de 1914 à nos jours. Paris. Éditions du Seuil. 
Schriewer, J. (2000). Estados-Modelo e sociedades de referência. Externalização em processos de modernização. In A. Nóvoa \& J. Schriewer (Eds.). A difusão mundial da Escola. Alunos professores, currículo - pedagogia (pp. 103-120). Lisboa: Educa.

Schriewer, J. \& Martinez, C. (2004). Constructions of internationality in Education. In G. Steiner-Khamsi (ed.). The global politics of educational borrowing and lending (pp. 29-53). New York and London: Teachers College, Columbia University.

Silveira, J. F. (1874). Relatório do Serviço do Commissariado Portuguez em Vienna de Austria. Lisboa: Imprensa Nacional.

Steiner-Khamsi, G. (Ed.) (2004). The global politics of educational borrowing and lending. New York and London: Teachers College, Columbia University.

Vasconcelos, A. (2000). Obra completa de Faria de Vasconcelos. (Vol. II, 1915-1920). Lisboa: Fundação Calouste Gulbenkian.

Wallerstein, I. (1974). The modern world system. New York: Academic Press.

Wortian, P., Blamire, R., Kearney, C., Quittre, V., de Gaer, E., \& Monseur, C. (2013). The use of ICT in Education: a survey of schools in Europe. European Journal of Education. Research, development and policy: ICT and Education: taking stock of progress and looking at the future, 48(1), 11-27.

\section{ACKNOWLEDGMENT}

This article is framed within the research actions of Development and Research Unit for Education and Training; Institute of Education of the University of Lisbon. The Development and Research Unit for Education and Training is founded by Foundation for Science and Tecnology. 